\title{
Development of Natural Sorbent for Decontamination of Drinking Water from Low Level of Transuranic and Other Long-lived Radionuclides
}

\section{Singhal RK ${ }^{*}$, Basu $\mathrm{H}$ and Reddy AVR}

Bhabha Atomic Research Centre, Trombay, Mumbai-400085, India

*Corresponding author: Singhal RK, Bhabha Atomic Research Centre, Trombay, Mumbai-400085, India, Tel: 91-22-25592233; Fax: 91-22-25505151; E-mail: rsinghal@barc.gov.in

Rec date: 25 June, 2014, Acc date: 30 July, 2014, Pub date: 01 August, 2014

Copyright: (c) 2014 Singhal R K et al., This is an open-access article distributed under the terms of the Creative Commons Attribution License, which permits unrestricted use, distribution, and reproduction in any medium, provided the original author and source are credited.

\begin{abstract}
Three different types of natural sorbents were developed using natural siliceous material, sodium alginate, and impregnation of goethite in alginate matrix. Experiments were carried out for decontamination of uranium, thorium, americium and plutonium by using siliceous material, Calcium-Alginate (Cal-Alg) and Goethite impregnated CalciumAlginate (Geo-Cal-Alg) respectively. These materials were tested for different conditions by varying their $\mathrm{pH}$ in the range of $1-8,95-98 \%$ Am-241 and Pu-239+240 sorbed by Cal-Alg and Geo-Cal-Alg beads respectively and experimental sorption capacity as evaluated were $\mathrm{Eu}^{3+}$ as a natural analogue for Am-241 and Pu-239+240 is 12.16 $\mathrm{mg} \mathrm{g}^{-1}$. Experimental results clearly showed that Th and $U$ sorption capacity is 1 and $0.3 \mu \mathrm{g} \mathrm{mg}{ }^{-1}$ (w/w) respectively in case of siliceous material. No change in various physicochemical characteristics of the potable water was observed after decontamination process.
\end{abstract}

Keywords: Natural sorbent; Siliceous material; Sodium alginate; Uranium; Thorium; Plutonium; Americium

\section{Introduction}

Drinking water contamination caused by Catastrophic incident like Dai ichi Nuclear Power Plant (NPP) Fukushima, Japan (11 March, 2011) and nuclear accidents like Chernobyl, USSR (March, 1986) demand scientists to evolve methodology for the decontamination of water without compromising on the drinking water quality. As per the reported literature data, from few $\mathrm{Bq} \mathrm{L}^{-1}$ to $100 \mathrm{BqL}^{-1}$ (approximately) of activity was reported in various drinking water sources in the region around accidental site [1-4].

In 2008, WHO published a third edition of the Guidelines for Drinking Water Quality [5]. These guidelines are not intended to provide a control on amounts of activity which may be discharged into drinking water sources, but are guidelines from which drinking water suppliers can determine whether action is necessary to reduce radioactivity levels in the water supply [5]. These levels relate to natural and artificially enhanced radioactivity in drinking water. The guidelines present a two-stage approach. Screening levels of $0.1 \mathrm{~Bq} \mathrm{~L}^{-1}$ and $1 \mathrm{~Bq} \mathrm{~L} \mathrm{~L}^{-1}$ for gross alpha and gross beta activity respectively have been retained from the first edition. If activity of drinking water is below this level, no further action is required [5,6]. Allowable concentration in case individual alpha emitting radionuclides like Th-232, Pu-239+240 and Am-241 in drinking water is $1 \mathrm{~Bq} \mathrm{~L}^{-1}$ as per the guidelines of WHO issued in 2008. This value is 10 times higher comparing to recommended gross alpha value. Limit for uranium in drinking water is $15 \mu \mathrm{g} \mathrm{L}^{-1}$, this is based on its chemical toxicity for the kidney instead of radiological toxicity. Details of the same are discussed elsewhere [7]. Thorium has number of isotopes in groundwater originating from both U-Th decay series. Under chemical equilibrium condition, ${ }^{232} \mathrm{Th}$ determines the chemical fate and speciation of all Th isotopes. A number of other Th isotopes (e.g., ${ }^{234} \mathrm{Th},{ }^{230} \mathrm{Th},{ }^{228} \mathrm{Th}$ ) also exist in seawater, albeit at lower concentrations, e.g., ${ }^{234} \mathrm{Th}$ is present in the ocean at atto-molar $\left(10^{-18}\right.$ M) concentration levels (Baskaran et al.). There is no specific limit for Th-232 in drinking water is given. In view of this; general guideline for gross alpha activity is taken into consideration. Therefore maximum allowable concentration in drinking water is $0.1 \mathrm{~Bq} \mathrm{~L}^{-1}$ [5]. Besides accidental scenario, radioactive constituents of drinking-water can result from naturally occurring radioactive species (e.g., radionuclides of the thorium and uranium decay series in drinking-water sources), in particular radium-226/228 and a few others, technological processes involving naturally occurring radioactive materials (e.g., the mining and processing of mineral sands or phosphate fertilizer production), Radionuclide discharged from nuclear fuel cycle facilities. Manufactured radionuclides (produced and used in unsealed form), and past releases of radionuclides into the environment, including water sources.

Siliceous material was derived from soil. Solid Phases in soils is dominated by siliceous material. Ninty percent of solid phase is inorganic and made up of primary minerals (typically inherited from geologic material) like quartz, feldspar and mica and secondary minerals (these minerals result from weathering transformations of primary) like Vermiculite and Semectite $[8,9]$.

Alginate is the most abundant marine biopolymer. The major source of alginate is found in the cell walls and the intracellular spaces of brown seaweed. The sodium alginate is generally used in various food items like jelly and hence its negative impact on the water quality is minimum. The use of alginate as an immobilizing agent in most applications rests in its ability to form heat-stable strong gels which can develop and set at room temperatures. It is the alginate gel formation with calcium ions which has been of interest in most applications.

A large number of studies have already been conducted to exhibit excellent adsorption ability for multivalent metal ions by calcium alginate beads $[8,10,11]$. The ability of alginate to form gels by ionexchange reaction with multivalent metal ions suggests its use as a 
metal adsorbent. Many recent studies have addressed the collection of heavy metals such as $\mathrm{Co}, \mathrm{Cu}, \mathrm{Cd}$ and $\mathrm{Zn}$ by alginic acid [12-15] (Konishi et al., Min et al., Jang et al., Nayak et al.). The alginic acid and alginates are thus likely to be potentially useful as adsorbents for the removal of radioactive nuclides from waste solutions. However a limited amount of information is available concerning the uptake behavior of radioactive nuclides on this polymer gel from potable water. The specificity of the alginate matrix for $\mathrm{Pu}-239+240$ is enhanced by impregnating $2 \%$ geothite $[\alpha \mathrm{FeO}(\mathrm{OH})]$ in the sodium alginate [11].

In the present study, decontamination of potable water from Uranium (U-238, 234, 235), Thorium (Th-232), Plutonium $(\mathrm{Pu}-239+240$ and Amricium (Am-241) was carried out without disturbing the water qualities using natural sorbent followed by the treatment with activated charcoal column. Major water quality parameters were monitored to ensure the water quality.

\section{Material and Methods}

\section{Spiking of the groundwater with $\mathrm{U}, \mathrm{Th}, \mathrm{Pu}$ and $\mathrm{Am}$}

Potable groundwater samples have been collected from three different sources (groundwater, rainwater and lake water) spread over a radial distance of $4 \mathrm{~km}$ from Trombay, Mumbai having latitude $19000^{\prime} 498(\mathrm{~N})$ and longitude 720 55'136. Samples were filtered through $0.45 \mu \mathrm{m}$ cellulose acetate membrane by using suction filtration. The stock solution of $\mathrm{Pu}-239+240$ and Am-241 in $0.2 \mathrm{M} \mathrm{HNO}_{3}$ and spectroscopy grade grade $\mathrm{Th}\left(\mathrm{NO}_{3}\right)_{4}$ and $\mathrm{UO}_{2}\left(\mathrm{NO}_{3}\right)_{2}$ solution of $1 \mathrm{~g} \mathrm{~L}^{-1}$ were used to spike the filtered groundwater at $\mathrm{pH} 4.0 \pm 0.3$. $\mathrm{pH}$ of the solution was controlled by using $0.1 \mathrm{~N} \mathrm{NaOH} / \mathrm{HNO}_{3}$. Various physicochemical parameters were measured before and after spiking the groundwater.

\section{Preparation of siliceous material}

Siliceous material was prepared by treating the soil particles (passed through to $2.0 \mathrm{~mm}$ sieve) with $\mathrm{HNO}_{3}$ and $\mathrm{H}_{2} \mathrm{O}_{2}$ for six hours on the hot plate under reflux conditions. Siliceous particle were decanted and washed with demineralised water until completely neutralized and dried in the oven at $80^{\circ} \mathrm{C}$. Details of the same were discuss elsewhere [9].

\section{Formation of calcium alginate beads}

A $2 \%$ solution (wt./vol.) of $\mathrm{Na}$ alginate in water was prepared with deionized water. This solution was taken in syringe and added to 0.2 $\mathrm{M} \mathrm{CaCl}_{2}$ solution drop-wise. $\mathrm{Na}$ alginate reacted with $\mathrm{CaCl}_{2}$ to form beads of $\mathrm{Ca}$ alginate. These beads were stored in $0.2 \mathrm{M} \mathrm{CaCl}_{2}$ solution and were thoroughly washed with deionized water before use. Calcium alginates beads so formed are stable in the temperature range $20-50^{\circ} \mathrm{C}$. The beads were permeable to water and had enough mechanical strength to be held in water column for 3-4 weeks. Goethite impregnated beads of Calcium Alginate was synthesized by mixing $2 \%$ (W/W) goethite in $2 \%$ solution of sodium alginate. Rest of the procedure is same as discussed above.

\section{Synthesis of goethite}

Synthesis of goethite was carried out at two different experimental conditions. In each case, $200 \mathrm{~mL}$ of suspension were prepared by mixing $100 \mathrm{~mL}$ of $\mathrm{FeSO}_{4} .7 \mathrm{H}_{2} \mathrm{O}$ solution with $100 \mathrm{~mL}$ of $\mathrm{NaOH}$ solution. The rotation speed of the magnetic stirrer was set at $760 \mathrm{rpm}$. The first experimental reference is defined by the following conditions. The reaction was carried out at room temperature $\left(\mathrm{T}=25^{\circ} \mathrm{C}\right)$ keeping the ratio (R) of $\left[\mathrm{FeSO}_{4}\right] /[\mathrm{NaOH}]$ as $0.2\left[\mathrm{FeSO}_{4} \cdot 7 \mathrm{H}_{2} \mathrm{O}=0.15 \mathrm{~mol} \mathrm{~L}-1\right.$; $\mathrm{NaOH}=0.75 \mathrm{~mol} \mathrm{~L}^{-1}$. Whereas in the second case $\mathrm{R}$ was 2.5 and the concentrations of $\mathrm{FeSO}_{4} \cdot 7 \mathrm{H}_{2} \mathrm{O}$ and $\mathrm{NaOH}$ was $0.5 \mathrm{~mol} \mathrm{~L}^{-1}$ and 0.20 mol L ${ }^{-1}$ respectively. With experimental condition (I), goethite forms directly from $\mathrm{Fe}(\mathrm{OH})_{2}$. With experimental condition (II), goethite forms from an intermediate Fe(II-III) compound [16,11].

\section{Measurement of physicochemical characteristics and concentration of major and trace metal ions}

Various physiochemical characteristics like $\mathrm{pH}$, conductivity and redox potential was measured by using $\mathrm{pH}$ meter (Model PICO $+\mathrm{Lab}$ India) and conductivity meter (Model PICO + Lab India). In case of redox potential measurement single pin platinum electrode was used instead of single pin glass electrode for $\mathrm{pH}$ Measurement. The concentration of various metal ions was either measured by Flame Atomic Absorption Spectrometry (FAAS) or Inductive Coupled Plasma-Optical Emission Spectroscopy (ICP-OES). The calibration for all the elements was carried out by using Fluka standards in $\mathrm{HNO}_{3}$ medium.

\section{Measurement of Pu-239+240 and Am-241}

The measurement of alpha activity of Pu-239+240 and Am-241 was carried out by using $\mathrm{ZnS}(\mathrm{Ag})$ detector having a background of 0.07 $\mathrm{cpm}$ and counting efficiency of $39 \%$. The efficiency of the system was evaluated by using Am-241 having an activity of $83.33 \mathrm{~Bq}$. This electrodeposited source was prepared by using standard solution of Am-241 received from IAEA, detailed of the same discussed elsewhere [6]. This electrodeposited source was calibrated against mixed nuclide source Am-241 from Amersham (AMR 33).

\section{Measurement of $\mathrm{U}$ and Th}

Determination of uranium and thorium was carried out by using simultaneous solid state detector Inductively Coupled Plasma Optical Emission Spectrometer (ICP-OES, model ACTIVA, from Horiba Jobin Yvon SAS, France). Intensity of emission was measured at two different wavelengths i.e. 398.582 and $367.011 \mathrm{~nm}$ in the case of uranium whereas thorium emission was measured at 401.913 and $283.232 \mathrm{~nm}$. The calibration of the instrument was carried out by using Aldrich standard solution of uranyl nitrate and thorium nitrate. ACTIVA utilizes a 2048x512 pixels, ultra-low noise and high quantum efficiency Charge Coupled Device (CCD) solid-state detector. ACTIVA includes a unique optical design featuring a $0.64 \mathrm{~m}$ CzernyTurner optical system and holographic gratings of 4343 grooves per $\mathrm{mm}$ and 2400 grooves per $\mathrm{mm}$, covering the full $6 \mathrm{~mm}$ height of the plasma; "Normal Analytical Zone Multi-WAV" acquisition mode provides complete sample fingerprinting of 75 elements in less than 30 seconds. It gives resolution up to $10 \mathrm{pm}$. Concentrations of uranium and thorium in different samples was also validated by using alpha spectrometry.

\section{Attenuated total reflectance- fourier transform infrared spectroscopy (ATR-FTIR)}

ATR-FTIR spectrum of calcium alginate beads was recorded at various stages by using fourier transform spectrometer "Spectrum One (Bruker)" equipped with the universal ATR as an internal reflection 
Citation: Singhal RK, Basu H, Reddy AVR (2014) Development of Natural Sorbent for Decontamination of Drinking Water from Low Level of Transuranic and Other Long-lived Radionuclides . J Environ Anal Chem 1: 113. doi:10.4172/2380-2391.1000113

Page 3 of 7

accessory having composite Zinc Selenide (ZnSe) and Diamond crystal. The Spectra was recorded in the wavelength range of 500-4000 $\mathrm{cm}^{-1}$ with a spectrum resolution of $4 \mathrm{~cm}^{-1}$.

\section{Characterization of goethite}

Malvern, Zeta-sizer nano zs with MPT-2 auto-titrator was used for the measurement of hydrodynamic diameter of the goethite suspension. This technique is based on Dynamic Light Scattering (DLS) and measure the hydrodynamic diameter in the range of size 0.6 $\mathrm{nm}-6 \mu \mathrm{m}, 1.5 \mathrm{~mL}$ of the aliquots were taken in the transparent cell. Goethite characterization in dry stage was done by PXRD (Powder Xray Diffraction) and ATRFTIR (Attenuated Total Reflectance Fourier Transform Infrared) Spectroscopy. SEM-EDS (Scanning Electron Microscope with energy dispersive spectrometry) were used for morphology and elemental characterization of goethite. Siliceous material/Calcium alginate beads/goethite impregnated calcium alginate \& granular activated charcoal column.

\section{Siliceous material/Calcium alginate beads/goethite impregnated calcium alginate and granulated activated charcoal column}

It was prepared by putting $20 \mathrm{~g}$ (wet weight) of each sorbent and 10 g of granulated activated charcoal separately in glass columns $(20 \mathrm{~cm}$ long and $0.8 \mathrm{~cm}$ diameter). In case of calcium alginate, experiments were carried out in locally designed columns having a cup (diameter $36 \mathrm{~mm}$ which can hold a volume of 1 liter) on top. Before elution from the natural sorbent column, holdup time of 30 and 100 minutes was given in case of $T h$ and $U$ respectively. The eluted solutions from the natural sorbent columns were passed through activated charcoal column. The rate of elution was maintained at a speed of $2 \mathrm{~mL} \mathrm{~min}-1$ in both the column.

\section{Results and Discussion}

The important water quality parameters monitored for the potable water collected from three different sources (groundwater, rainwater, lakewater) and are given in the Table 1. From this table it is clear that except total hardness which is the measure of concentration of calcium and magnesium carbonate and total dissolved solid (TDS), there is not much variation in concentration of different parameters. There is a slight variation in the concentration of TDS but still much below than the permissible limit [5].

\begin{tabular}{|l|l|l|l|}
\hline Parameters & \multicolumn{3}{l|}{ Average Value $\left(\mu \mathrm{L} \mathrm{L}^{-1}\right)$} \\
\hline & Ground water & Rain water & Lake Water \\
\hline $\mathrm{pH}$ & $7.7 \pm 0.32$ & $4.2 \pm 0.21$ & $5.1 \pm 0.19$ \\
\hline Conductance $(\mu \mathrm{S})$ & $280 \pm 10$ & $120 \pm 10$ & $100 \pm 16$ \\
\hline Total hardness & $120 \pm 4$ & $65 \pm 2.7$ & $70 \pm 3.2$ \\
\hline $\mathrm{HCO}_{3}^{-}$ & $65 \pm 3$ & $25 \pm 2$ & $32 \pm 1.3$ \\
\hline $\begin{array}{l}\text { Dissolved Organic Carbon } \\
(\mathrm{DOC})\end{array}$ & $0.8 \pm 0.02$ & $0.3 \pm 0.08$ & $1.30 \pm 0.08$ \\
\hline Total Dissolved Solid $^{-1}$ & $300 \pm 20$ & $150 \pm 10$ & $100 \pm 5$ \\
\hline Turbidity (NTU) & $6 \pm 0.4$ & $2 \pm 0.1$ & $4 \pm 0.3$ \\
\hline $\mathrm{PO}_{4}^{3-}$ & $0.35 \pm 0.02$ & $0.15 \pm 0.02$ & $0.32 \pm 0.03$ \\
\hline
\end{tabular}

\begin{tabular}{|l|l|l|l|}
\hline $\mathrm{NO}_{3}^{-}$ & $4.5 \pm 0.8$ & $1.2 \pm 0.5$ & $1.8 \pm 0.2$ \\
\hline $\mathrm{F}^{-1}$ & $0.07 \pm 0.01$ & $0.03 \pm 0.01$ & $0.02 \pm 0.01$ \\
\hline Calcium & $24.23 \pm 1.20$ & $12 \pm 0.4$ & $14 \pm 1.3$ \\
\hline Magnesium & $7.4 \pm 1.2$ & $5.6 \pm 1.1$ & $6.7 \pm 1.3$ \\
\hline Arsenic $\left(\mathrm{ng} \mathrm{L}^{-1}\right)$ & $<5$ & $<5$ & $<5$ \\
\hline Cadmium & $<0.01$ & $<0.01$ & $<0.01$ \\
\hline Gross Alpha $\left(\mathrm{Bq} \mathrm{L}^{-1}\right)$ & $<0.1$ & $<0.1$ & $<0.1$ \\
\hline Gross Beta $\left(\mathrm{Bq} \mathrm{L}^{-1}\right)$ & $<1.1$ & $<1.1$ & $<1.1$ \\
\hline
\end{tabular}

Table 1: Characteristics of potable water collected from different sources

\section{Formation of calcium alginate beads}

Calcium alginate beads formation from solution of sodium alginate involves a simple displacement reaction in which sodium ions are replaced by $\mathrm{Ca}^{2+}$ These beads have enough mechanical strength and were stable for 3- 4 weeks. Details of the same were discussed elsewhere [7,9]

\section{Characterization of siliceous material and calcium-alginate (Cal-Alg) and goethite-calcium-alginate (Goe-Cal-Alg) beads}

Detailed characterization of natural sorbent developed for this work was done by using ATR-FTIR, PXRD, SEM-EDS. Details of the same were discussed elsewhere $[7,9,11,17,18]$.

\section{pH optimization for sorption of Am-241 and Pu-239+240 and by calcium alginate beads ( Cal-Alg) and goethite impregnated calcium alginate beads ( Goe-Cal-Alg) column}

In order to have effective sorption of $\mathrm{Am}-241$ and $\mathrm{Pu}-239+240$ by the Cal-Alg and Goe-Cal-Alg beads column respectively, $\mathrm{pH}$ is optimized. Figure 1 shows the sorption profile of Am-241 and $\mathrm{Pu}-239+240$ having a concentration of $500 \mathrm{~Bq} \mathrm{~L}^{-1}$ at different $\mathrm{pH}$.

From the Figure 1 it is clear that at $\mathrm{pH} 4$ more than 99\% Am-241 and $\mathrm{Pu}-239+240$ is sorbed by Cal-Alg and Goe-Cal-Alg beads respectively. This is attributed due to the ionization of $\mathrm{COOH}$ group of the alginate biopolymers and goethite was also partially ionized to $\mathrm{FeO}^{-}$and $\mathrm{OH}^{-}[19,20]$. At this $\mathrm{pH}$ maximum ionization is achieved and these ionizable sites are available for binding with $\mathrm{Am}^{3+}$ and $\mathrm{Pu}^{4+}$ At $\mathrm{pH}$ greater than 4, due to higher concentration of $\mathrm{OH}^{-}$ions the Am is present as neutral species $\mathrm{Am}(\mathrm{OH})_{3}$ and $\mathrm{Pu}$ as $\mathrm{Pu}(\mathrm{OH})_{4}$ with a small fraction as $\mathrm{Pu}(\mathrm{OH})_{6}$ and not available to bind with $\mathrm{COO}^{-}$and $\mathrm{FeO}^{-}$. 
Citation: Singhal RK, Basu H, Reddy AVR (2014) Development of Natural Sorbent for Decontamination of Drinking Water from Low Level of Transuranic and Other Long-lived Radionuclides . J Environ Anal Chem 1: 113. doi:10.4172/2380-2391.1000113

Page 4 of 7

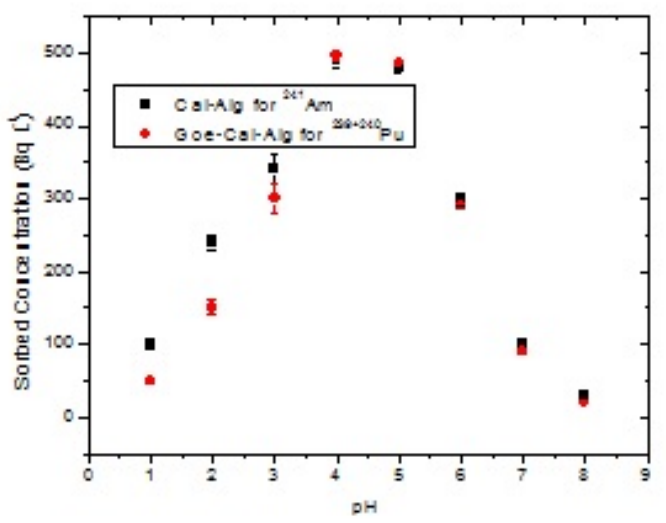

Figure 1: Variation in sorption of Am-241 and $\mathrm{Pu}-239+240$ on CalAlg and Goe-cal-Alg column respectively with $\mathrm{pH}$

\section{Optimization of $\mathrm{pH}$ for the sorption of $\mathrm{U} \&$ Th on siliceous material}

Sorption of ions to particle surfaces is strongly $\mathrm{pH}$ dependent, with cations generally showing increasing sorption with increasing $\mathrm{pH}$, and anions showing increasing sorption with decreasing $\mathrm{pH}$. In order to see the effects of $\mathrm{pH}$ on the sorption of $\mathrm{U}$ and $\mathrm{Th}$ on siliceous matter experiments were carried out in the $\mathrm{pH}$ range of 1-6, keeping the constant concentration of $\mathrm{Th} / \mathrm{U}\left(10 \mu \mathrm{g} \mathrm{mL} \mathrm{m}^{-1}\right)$ and siliceous material $(500 \mathrm{mg})$. The maximum sorption was observed at $\mathrm{pH} 4$ for both $\mathrm{U}$ and Th. However in case of uranium maximum sorption is only $70 \%$ whereas for thorium it is $94 \%$ (Figure 2).

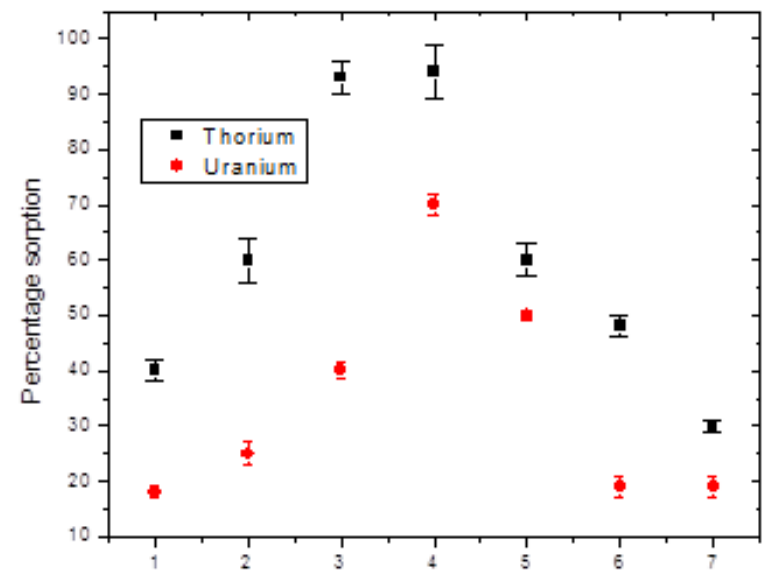

Figure 2: Variation in sorption of uranium and thorium on siliceous material column with $\mathrm{pH}$

Siliceous materials were developed by destruction of organic layers from soil particles therefore elevated level of thorium sorption compare to uranium is mainly due to its particle reactive nature. As other major complexing ligands such as humic/fulvic acid are not present on the surface of soil therefore only driving force for the sorption of $U$ and Th is "particles surface activity". This particle reactive driving force favor thorium due to its single predominant oxidation state (IV) leading to constant ionic potential. Enrichment of Th(IV) in marine sediment having more than $70 \%$ siliceous matter was also reported by Basu et al. [17].

\section{Variation of sorption of Am-241, Pu-239+240, $\mathrm{U}$ and Th by Cal-Alg, Geo-Cal-Alg beads and siliceous material respectively with time}

Figure 3 gives variation of sorption of Am-241 and $\mathrm{Pu}-239+240$ with time whereas the same in case of $U$ \& Th by siliceous material is shown in Figure 4. From these figures, it is evident that equilibrium sorption time in case of $\mathrm{Am}$ and $\mathrm{Pu}-239+240$ by Cal-Alg and Geo-CalAlg beads is 100 minutes whereas the same in case of siliceous material is 30 minutes for Th and 100 minutes for uranium. In view of this, elution of the spiked samples in all the experiment was done after reaching the equilibration time, maintaining the elution rate of $2 \mathrm{~mL}$ $\mathrm{m}^{-1}$.

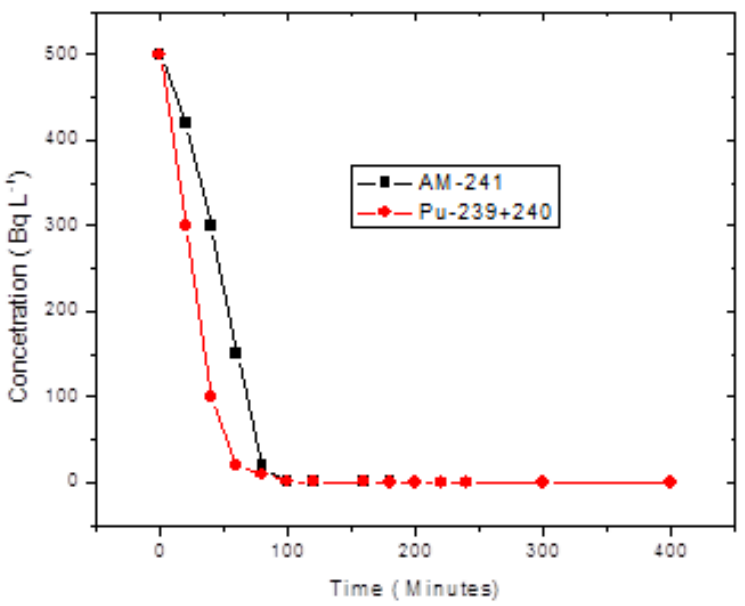

Figure 3: Variation in sorption of Am-241 and pu-239+240 on siliceous material column with time

\section{Evaluation of the sorption capacity of the column for Am-241 and Pu-239+240}

To meet the radiological regulatory requirement of the lab, sorption capacity was evaluated with $\mathrm{Eu}^{3+}$. 
Citation: Singhal RK, Basu H, Reddy AVR (2014) Development of Natural Sorbent for Decontamination of Drinking Water from Low Level of Transuranic and Other Long-lived Radionuclides . J Environ Anal Chem 1: 113. doi:10.4172/2380-2391.1000113

Page 5 of 7

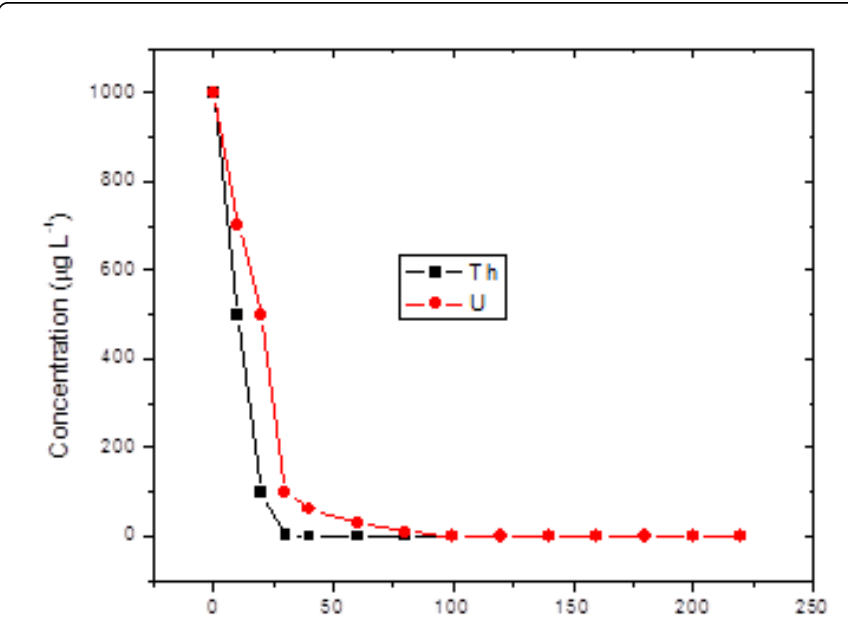

Figure 4: Variation in sorption of uranium and thorium on siliceous material column with time

Since the amount of actinides $(\mathrm{Pu}, \mathrm{Am})$ in environmental sample is at ultra-trace level. In view this europium (Eu) was used as natural analog for $\mathrm{Pu} \& \mathrm{Am}$. Using Eu is necessary when macro amounts are needed for evaluation of sorption capacity. Sorption isotherms of $\mathrm{Eu}^{3+}$ for alginate gels were obtained in a wide range of initial concentration of $\mathrm{Eu}^{3+}$ from $1.3 \times 10^{-4}$ to $6.6 \times 10^{-2} \mathrm{M}$. The stability of the higher oxidation states of the transuranium elements typically europium is the heavy homolog of americium and plutonium decreases with increasing atomic number $[10,19,20,21]$. In agreement with this, the trivalent state of americium is the most stable oxidation state, and it is the homolog of americium, $\left[\mathrm{Am}^{3+}\right.$ and $\mathrm{Pu}^{4+}$ radius $=0.99 \mathrm{AO}$ and $1 \mathrm{AO}$ respectively [22]. The equilibrium amount of $\mathrm{Eu}^{3+}$ adsorbed on alginate gel increased with equilibrium concentration of $\mathrm{Eu}^{3+}$, and then approached a constant value at $\mathrm{Eu}^{3+}$ concentration. Experimentally observed sorption capacity is $12.16 \mathrm{mg} \mathrm{g}^{-1}$ which is very close to the Langumir constant $\mathrm{Q}_{0}$ (see Figure 5),

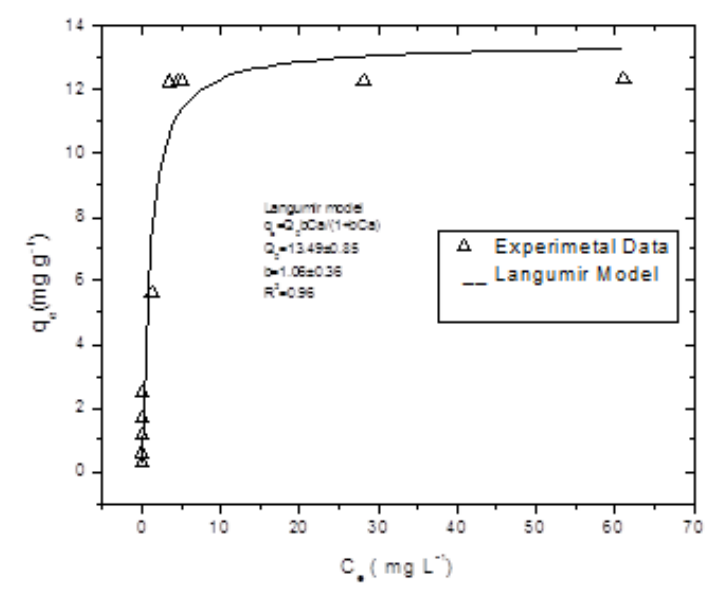

Figure 5: Langumir isotherm for $\mathrm{Eu}^{3+}$ on calcium alginate column

Which is measure of the monolayer adsorption capacity, as obtained, $13.49 \pm 0.85 \mathrm{mg} \mathrm{g}^{-1}$. Figure 6, gives the experimental fit of
Freundlich isotherm model where constant $\mathrm{k}$ and $\mathrm{n}$ are related to the strength of the adsorptive bond and the bond distribution. This model assumes that the ratio of the amount of solute adsorbed on to a given mass of adsorbent to the concentration of the solute in the solution is not constant at different concentrations. As clear from the Figure 5 and 6 experimental data are very close to the Langmuir-type adsorption model.

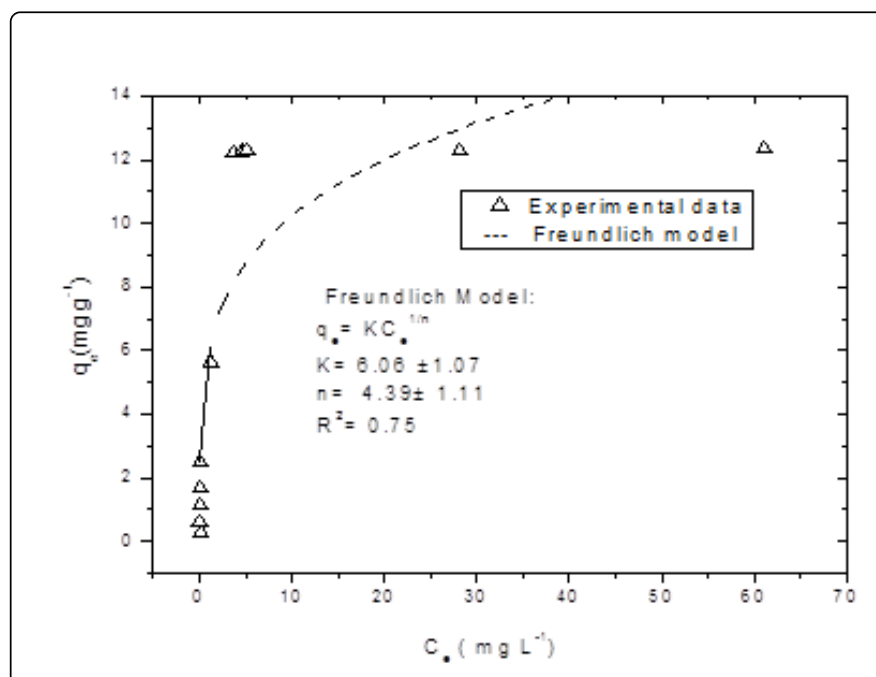

Figure 6: Freundlich isotherm for $\mathrm{Eu}^{3+}$ on calcium alginate column

\section{Sorption of $U$ and $T h$ on siliceous material}

Figure 7, gives the variation in percentage sorption of $U$ and $T h$ keeping the concentration of adsorbate same $(50 \mathrm{mg}$ ) while the concentration of $U$ and Th vary between $1 \mu \mathrm{g} \mathrm{mL}^{-1}$ to $10 \mu \mathrm{g} \mathrm{mL}^{-1}$ ( Total volume $50 \mathrm{~mL}$ ). From this Figure it is clear that uniform sorption $\left(\mu \mathrm{g} \mathrm{mg}^{-1}\right)$ was observed irrespective of $\mathrm{Th} / \mathrm{U}$ concentration. Experiments clearly show that the sorption capacity of silicious material for thorium and uranium was 1 and $0.3 \mu \mathrm{g} \mathrm{mg} \mathrm{g}^{-1}$ respectively for different concentrations of thorium and uranium. From these experimental results it is clear that in the absence of any complexing ligand such as humic/fulvic acid on the surface of soil "particle's surface activity" is the only driving force to sorb Th and $U$ on the siliceous material. In order to understand the various species of uranium present at $\mathrm{pH} 3-4$, work carried out by [23] using computer program EQ3/6 was used. As per this uranium speciation model at $4 \times 10^{-4} \mathrm{M}$ initial uranium solutions showed that the uncomplexed uranyl ion $\mathrm{UO}_{2}{ }^{2+}$ dominates the $\mathrm{U}(\mathrm{VI})$ speciation at $\mathrm{pH}$ 3-4 and with the increase of $\mathrm{pH}$, fraction of $\mathrm{UO}_{2}{ }^{2+}$ decreases sharply [24-28]. 
Citation: Singhal RK, Basu H, Reddy AVR (2014) Development of Natural Sorbent for Decontamination of Drinking Water from Low Level of Transuranic and Other Long-lived Radionuclides . J Environ Anal Chem 1: 113. doi:10.4172/2380-2391.1000113

Page 6 of 7

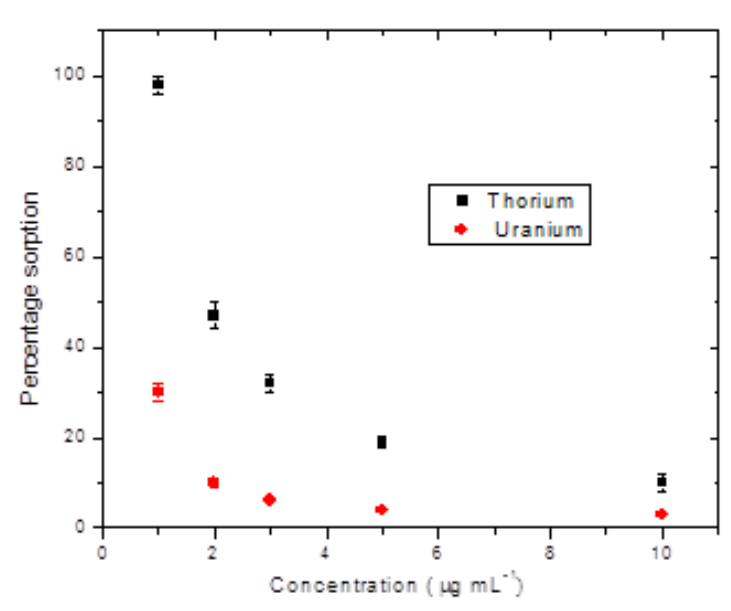

Figure 7: Variation in sorption of uranium and thorium on siliceous material column at different concentration of uranium and thorium
Whereas in case of Thorium, no change in sorption was observed with a change in $\mathrm{pH}$. This is because chemical properties of Th are relatively simple. Th has only one stable oxidation state, IV, under all redox conditions in natural waters, and Th(IV) ions are extremely particle reactive. The reactions and equilibrium equations for sorption of Th on silica are very similar to the proton exchange [29-34].

\begin{tabular}{|c|c|c|c|c|c|c|c|}
\hline \multirow{3}{*}{$\begin{array}{l}\text { Parameters } \\
\text { After Passing Through }\end{array}$} & & \multicolumn{6}{|c|}{ Average Value $\left(\mu \mathrm{g} \mathrm{L}^{-1}\right)$} \\
\hline & \multicolumn{2}{|l|}{ Cal-Alg column } & \multicolumn{2}{|c|}{ Goethite-Cal-Alg. Column } & \multicolumn{3}{|c|}{ Siliceous matter Column } \\
\hline & $\begin{array}{l}\text { Calcium Alginate } \\
\text { column }\end{array}$ & $\begin{array}{l}\text { Activated Charcoal } \\
\text { Column }\end{array}$ & $\begin{array}{l}\text { Calcium Alginate- } \\
\text { Goethite column }\end{array}$ & Activated Charcoal Column & $\begin{array}{l}\text { Silicious } \\
\text { column }\end{array}$ & $\begin{array}{l}\text { Activated } \\
\text { Column }\end{array}$ & Charcoal \\
\hline $\mathrm{pH}$ & $4.2 \pm 0.3$ & $4.1 \pm 0.4$ & $4.3 \pm 0.3$ & $4.4 \pm 0.3$ & $5.0 \pm 0.4$ & $5.0 \pm 0.4$ & \\
\hline Conductance $(\mu \mathrm{S})$ & $230 \pm 15$ & $220 \pm 9$ & $125 \pm 8$ & $132 \pm 11$ & $100 \pm 7$ & $110 \pm 5$ & \\
\hline Total hardness & $70 \pm 10$ & $65 \pm 10$ & $78 \pm 8.7$ & $55 \pm 8.7$ & $62 \pm 6.2$ & $62 \pm 6.2$ & \\
\hline $\mathrm{HCO}_{3}^{-}$ & $55 \pm 6$ & $55 \pm 6$ & $35 \pm 1.3$ & $35 \pm 1.3$ & $30 \pm 1.3$ & $30 \pm 1.3$ & \\
\hline $\begin{array}{ll}\text { Dissolved } & \text { Organic } \\
\text { Carbon ( DOC) } & \end{array}$ & $1.0 \pm 0.02$ & $1.0 \pm 0.02$ & $0.8 \pm 0.08$ & $0.8 \pm 0.08$ & $1.30 \pm 0.12$ & $1.30 \pm 0.12$ & \\
\hline Total Dissolved Solid & $260 \pm 10$ & $250 \pm 15$ & $140 \pm 7$ & $145 \pm 8$ & $110 \pm 12$ & $123 \pm 5$ & \\
\hline Turbidity (NTU) & $3 \pm 0.2$ & $3 \pm 0.4$ & $3 \pm 0.2$ & $3 \pm 0.1$ & $5 \pm 0.1$ & $5 \pm 0.12$ & \\
\hline $\mathrm{Ca}^{2+}$ & $46.16 \pm 3.45$ & $19.6 \pm 3.20$ & $41 \pm 1.2$ & $17 \pm 1.7$ & $15 \pm 1.5$ & $14 \pm 1.4$ & \\
\hline $\mathrm{NO}_{3}^{-}$ & $6.0 \pm 0.3$ & $4 \pm 0.5$ & $8.2 \pm 0.2$ & $2.2 \pm 0.8$ & $3.6 \pm 0.4$ & $3.6 \pm 0.4$ & \\
\hline $\mathrm{Cl}^{-}$ & 280 & 250 & 400 & 350 & 450 & 380 & \\
\hline $\mathrm{Na}^{+}$ & $440 \times 10^{3}$ & $280 \times 10^{3}$ & $360 \times 10^{3}$ & $280 \times 10^{3}$ & $340 \times 10^{3}$ & $285 \times 10^{3}$ & \\
\hline DO ( Dissolved Oxygen) & $6.9 \pm 1.6$ & $6.5 \pm 1.4$ & $6.9 \pm 1.3$ & $7.1 \pm 1.3$ & $6.8 \pm 1.3$ & $6.5 \pm 1.3$ & \\
\hline Gross Alpha $\left(\mathrm{Bq} \mathrm{L}^{-1}\right)$ & $<0.1$ & $<0.1$ & $<0.1$ & $<0.1$ & $<0.1$ & $<0.1$ & \\
\hline Gross Beta $\left(\mathrm{Bq} \mathrm{L}^{-1}\right)$ & $<1.1$ & $<1.1$ & $<1.1$ & $<1.1$ & $<1.1$ & $<1.1$ & \\
\hline
\end{tabular}

Table 2: Characteristics of the water samples after decontamination (After passing through the natural sorbent column i.e. column of either of Cal-Alg; Goe-Cal-Alg; Silicious material) and granulated activated charcoal column 


\section{The purification of process water from natural sorbent using activated charcoal column}

After having decontamination of $\mathrm{U}, \mathrm{Th}, \mathrm{Pu}$ and Am from the water samples by using natural sorbent column, solution were further passed through the charcoal column for purification of potable water. Table 2 gives the values obtained for various parameters. From the data it is clear that the parameters $\left(\mathrm{Ca}^{2+}, \mathrm{NO}_{3}{ }^{-1}, \mathrm{Na}^{+}\right.$and $\left.\mathrm{Cl}^{-}\right)$are not much different from the original parameters given in the Table 1. Small variation in the parameters in both the cases may be due to the absorption of some of the metal ions at the charcoal column.

\section{Conclusion}

Low level of $\mathrm{U}, \mathrm{Th}, \mathrm{Pu}$ and Am were sorbed from potable water without disturbing the various water quality parameters by using natural sorbents (Siliceous matter, Cal-Alg and Goe-Cal-Alg). Control on the concentration of $\mathrm{Ca}^{2+}, \mathrm{NO}_{3}{ }^{-1}, \mathrm{Na}^{+}$and $\mathrm{Cl}^{-}$was achieved by using activated charcoal column in conjugation with natural sorbent.

\section{Acknowledgement}

The authors sincerely acknowledge the encouragement and guidance provided by Prof. B.N. Jagatap, Director Chemistry group.

\section{References}

1. Buesseler K, Aoyama M, and Fukasawa M (2011) Impacts of the Fukushima Nuclear Power Plants on Marine Radioactivity. Environ Sci Technol 45: 9931-9935.

2. Garnier LJ, Beaugelin SK, Hinton TG (2011) Fukushima wildlife dose reconstruction signals ecological consequences. Environ. Sci.Technol 45 5077-5078.

3. Chino M, Nakayama H, Nagai H, Terada H, Katata G et al. (2011) Preliminary estimation of release amounts of I-131 and Cs-137. accidentally discharged from the Fukushima Daiichi nuclear power plant into the atmosphere. J Nucl Sci Technol 48: 1129-1134.

4. TEPCO T. E. P. C. TEPCO News Press Releases http:// www.tepco.co.jp/en/index-e.html (accessed July 31, 2011).

5. WHO (2008) Guidelines for Drinking-water Quality. Third edition p. 7-300; ISBN 9789241547611 (WEB version).

6. Singhal RK, Usha N (2009) Improved method for the complete separation of gross alpha and beta in drinking water. Desalination and Water treatment 12: 143-148.

7. Singhal RK, Joshi S, Tirumalesh K, Gurg RP (2004) Reduction of uranium concentration in well water by Chlorella (Chlorella pyrendoidosa) a fresh water algae immobilised in calcium alginate. J. Radioanal. Nucl. Chem. 261: 73-78.

8. Rosaria C, Sciortino M, Alonzo G, Schrijver AD, Pagliaro M (2011) From Molecules to Systems: Sol-Gel Microencapsulation in Silica-Based Materials. Chem Rev 111: 765-789.

9. Singhal RK, Basu H, Manisha V, Reddy AVR, Mukherjee T (2011) Removal of Low Level of Am-241 From Potable Water originated from Different Geochemical Environments by Calcium Alginate. Desalination 280: 313-318.

10. Mimura H, Ohta H, Hoshi H, Akiba K, Wakui Y et al. (2001) Uptake behavior of americium on alginic acid and alginate polymer gels. Radioanal Nucl Chem 247: 33-38.

11. Singhal RK, Basu H, Reddy AVR (2013) Removal of environmental level of $239+240 \mathrm{Pu} \& 241 \mathrm{Am}$ from groundwater by using humic coated colloidal suspension of goethite $(\alpha \mathrm{FeO}(\mathrm{OH}))$. J. Radioanal Nucl Chem 295: 1345-1351.
12. Konishi Y, Asai S, Midoh Y, Oku M (1993) Recovery of zinc, cadmium, and lanthanum by biopolymer gel particles of alginic acid. Separ Sci Technol 28: 1691-1702.

13. Min JH, Hering JG (1998) Arsenate Sorption by Fe(III)-Doped Alginate Gels. Water Res 32: 1544-1552.

14. Jang LK, Nguyen D, Geesey GG (1999) Selectivity of alginate gel for Cu over $\mathrm{Zn}$ when acidic conditions prevail. Water Res 33: 2817-2825.

15. Nayak D, Lahiri S (2006) Biosorption of toxic, heavy, no-carrier-added radionuclides by calcium alginate beads. J Radioanal Nucl Chem 267: 59-65

16. Gilbert F, Refait P, Leveque F, Remazeilles C, Conforto E (2008) Synthesis of goethite from $\mathrm{Fe}(\mathrm{OH}) 2$ precipitates-Influence of $\mathrm{Fe}(\mathrm{II})$ concentration and stirring speed. J Phys Chem Solids 69: 2124.

17. Basu H, Singhal RK, Pimple MV, Manisha V, Bassan MKT et al. (2011) Development of naturally occurring siliceous material for the preferential removal of thorium from U-Th from aquatic environment. J Radioanal Nucl Chem 289: 231-237.

18. Basu H, Singhal RK, Pimple MV, Manisha V, Bassan MKT et al. (2013) Synthesis and characterization of alumina impregnated alginate beads for fluoride removal from potable water. Water Air Soil Pollut 224: 1572-1584.

19. Apel ML, Tot ma AE (1993) Determination of kinetics and diffusion coefficients of metal sorption on Ca-alginate beads. Can J Chem Eng 71: 652-656.

20. Chen H, Tendeyong F, Yiacoumi S (1997) Equilibrium and kinetic studies of copper ion uptake by calcium alginate. Environ Sci Technol 31: 1433-1439.

21. Asprey LB, Penneman RA (1961) First Observation of Aqueous Tetravalent Amercium. J Amer Chem Soc 83: 2200-2206.

22. Asprey LB, Penneman RA (1962) Preparation and Properties of Aqueous Tetravalent Amercium. Inorg Chem 1: 134-136.

23. Wolery TJ (1992) Report UCRLMA-110662 part 1: Lawrence Livermore National Laboratory, California, USA.

24. Meinrath G (1996) Coordination of uranyl (VI) carbonate species in aqueous solutions. J Radioanal Nuc Chem 211: 349-362.

25. Meinrath G (1997) Uranium (VI) speciation by spectroscopy. J Radioanal Nuc Chem 224: 119-126.

26. Elliot HA, Liberati MR, Huang CP (1986) Competitive adsorption of heavy metals by soils. J. Environ. Qual 15 : 214-219.

27. Erdem E, Karapinar N, and Donat R (2004) The removal of heavy metal cations by natural zeolites. J Colloid Interf Sci 280: 309-314.

28. Reza S, Seyed Y, Ahmadib J, Shemirania F, Jamalic MR, Niasari MS (2009) Simultaneous extraction and preconcentration of uranium and thorium in aqueous samples by new modified mesoporous silica prior to inductively coupled plasma optical emission spectrometry determination Talanta 80: 212-217.

29. O"sthols E (1995) Thorium sorption on amorphous silica. Geochim Cosmochim Acta 59: 1235-1249.

30. Osthols E, Manceau A, Farges F, Charlet L (1997) Adsorption of thorium on amorphous silica: an EXAFS study. J Colloid Interface Sci 194: 10-21.

31. Quigley M, Honeyman BD, Santschi PH (1996) Thorium sorptionin the marine environment: equilibrium partitioning at the hematite/water interface,sorption/desorption kinetics and particle tracing. Aquat Geochem 1: 277-301.

32. Yong P, Macaskie LE (1998) Bioaccumulation of lanthanum, uranium and thorium, and use of a model system to develop a method for the biologically-mediated removal of plutonium from solution. J Chem Technol Biotechnol 71: 15-26.

33. Chen J, Yiacoumi S (1997) Biosorption of metal ions from aqueous solutions. Separ Sci Technol 32: 51-69.

34. Hirose K, Tanoue E (1994) Thorium-particulate matter interaction. Thorium complexing capacity of oceanic particulate matter: theory. Geochim Cosmochim Acta 58: 1-7. 